\title{
Learning to Litigate: the Relationship Between Past Litigation Experience and Litigation Outcomes in the Chinese Intellectual Property System
}

\author{
Kristina Vaarst Andersen · Karin Beukel • Beverly B. Tyler
}

Accepted: 13 September 2021 / Published online: 30 November 2021

(C) The Author(s) 2021

\begin{abstract}
Intellectual property (IP) and the protection of IP is of increasing importance to firms' competitiveness, and firms must be able to defend their IP when it is infringed upon. In most markets, IP and the defense of IP is a stringent legal process, but in developing markets and markets undergoing changes, this is not necessarily so. The Chinese IP system and protection is comparatively new, and the system is still under development. In this study, we analyze the relationship between firms' previous litigation experience and litigation outcomes using a sample of 10,211 court cases tried in China between 2001 and 2009. We find that despite litigation being a rare event for most firms, plaintiffs' prior litigation experience and especially prior successful litigation experience or experience with specific case types is related to their likelihood of a positive outcome. However, plaintiffs' successful application of prior litigation experience is contingent on the type of litigation case.
\end{abstract}

Keywords IP litigation · Organizational learning $\cdot$ Litigation experience $\cdot$ Learning to litigate

\footnotetext{
This paper was originally submitted and independently peer-reviewed at Schmalenbach Business Review, one of SBUR's predecessor journals. It has been accepted by the same Editor-in-Chief for publication in the successor journal SBUR.
}

Kristina Vaarst Andersen $(\varangle)$

University of Southern Denmark, Campusvej 55, 3250 Odense, Denmark

E-Mail: vaarst@sam.sdu.dk

Karin Beukel

Circular Food Technology, Copenhagen, Denmark

E-Mail: kb@circularfoodtech.com

Beverly B. Tyler

Pamplin College of Business, Department of Management, Virginia Tech,

Blacksburg, VA 24061, USA

E-Mail: beverlyt@vt.edu 
JEL D83 $\cdot \mathrm{K} 41 \cdot \mathrm{N} 45 \cdot \mathrm{O} 43$

\section{Introduction}

Intellectual property (IP) is a tool to appropriate value from innovation and protect the firm's innovation investments (Rivette and Kline 2000; Somaya 2012; Teece 1986). Therefore, IP is an essential part of the firm's strategic positioning (Teece et al. 1997). However, partners, competitors, and infringers can use the firm's IP inappropriately. Industry participants may consider ownership boundaries to be ambiguous and may try to test the firm's commitment to protecting its market position or try to expropriate the firm's IP and use it in new markets (Somaya 2003; The Economist 2010). Given the desire to secure investments in innovation, and the efforts made to use IP inappropriately, it is not surprising that the number of IP applications globally has doubled since the late 2000s, and that litigation has increased in all major world jurisdictions (Alcacer et al. 2015).

Litigation research in law and economics is the prime contributor to our current understanding of the reasons why firms take other firms to court for using their IP without permission, and of the factors that affect the plaintiff's likelihood of winning. The motivations for initiating litigation include efforts to protect core technical assets (Lanjouw and Schankerman 2001; Somaya, 2003), build reputation (Lanjouw and Schankerman 2001; Tansey et al. 2005), and constrain knowledge spillovers through employee turnover (e.g. Agarwal et al. 2009; Lanjouw and Schankerman 2001; Polidoro and Toh 2011; Somaya 2003). Key factors found to affect the likelihood of plaintiff success are type of technology (Lanjouw and Lerner 1998), corporate status and income (Janicke and Ren 2006), and a domestic plaintiff's advantage over a foreign defendant (Janicke and Ren 2006; Moore 2003). Although litigation research provides a cursory understanding of firms' motivations to litigate IP and the factors that influence their success, it does not offer insights into the relationship between firms' experience with previous litigation and their likelihood of a positive litigation outcome.

In this study, we address the question of how firms' litigation experience is related to their likelihood of achieving a successful outcome. We choose to study this in the context of the developing Chinese IP system, because the dynamics of an emerging system will increase the importance of the tacit elements of learning. To distinguish between whether firms learn from their prior experiences with IP litigation or if they merely learn to navigate the legal system, we distinguish between two different types of experience as well as their outcomes: infringement case experience versus contract case experience and their specific outcomes. If firms merely learn how to navigate and manipulate the legal system in their favor, we would expect no differences in the relationship between experience and outcome across these two types of cases. However, if firms actually learn how to protect their IP we would expect a stronger relationship between experience with infringement cases and infringement case outcomes, and between experience with contract cases contract case outcomes, although some learning in contract cases may be manifested as improvement in con- 
tracting over time (see Lumineau et al. 2011; Mayer and Argyres 2004; Vanneste and Puranam 2010 for examples of the learning to contract literature).

We analyze plaintiffs in 10,211 court cases litigated in China between 2001 and 2009. We choose the perspective of the plaintiff, because the plaintiff firm exerts the most agency in the case by choosing to initiate the litigation, and hence has better opportunity to utilize experience from earlier IP litigation than the defendant. China is an excellent context for three main reasons. First, the Chinese legal system is relatively new, and the period we observe covers allmost all of the Chinese litigation cases during the period of institutionalization of the system. Second, China has become the most IP active country in the world, overtaking the U.S. for numbers of patent applications in 2012, and applying for almost twice as many patents in 2015 than the U.S. Third, in the studied period Chinese firms tended to be very focused on the domestic market (Niosi and Tschang 2009), and consequently had little opportunity to gain experience with IP litigation outside the domestic legal system.

The data were collected by a U.K. based corporate service provider that trains nationals to systematically hand-collect data from all major Chinese courts; this enhances data reliability and consistency across the many regions of China. This comprehensive, reliable, and consistent data allows us to conduct what we believe to be the first study using a large sample of IP litigation data from China, which investigates the determinants of litigation outcomes within an institutional system that affects the innovative capacity of the worlds' largest economy (Whitley 2002).

Our study contributes to literature on organizational learning by extending organizational learning theory to the non-routine, rare event of litigation. It also contributes to the law and economics litigation literature by proposing a theoretical lens, which we label "learning to litigate", that can be applied in future studies on litigation.

\section{Learning to Litigate}

Organizational learning has been defined as the process of creating, maintaining, and transferring knowledge within an organization (Cyert and March 1963). The organizational learning literature focuses on how through repeated relatively homogeneous events, organizations accumulate experience that leads to learning (Argote 1999). This stream of research also suggests that positive outcomes strengthen firms' intent to learn, attention to detail, and the amounts of resources they allocate to learning (Ocasio 1997). But for most firms, IP litigation is a rare event (Lanjouw and Lerner 1998; Somaya 2003), suggesting that they will not likely have the opportunity to build any routines or accumulate extensive experiences related to IP litigation. In support of this contention we know that despite the doubling of global patent applications over the last decade (Alcacer et al. 2015), only $1 \%$ of the patents applied 
for end in litigation ${ }^{1}$. Regardless, firms may use learning from prior experiences when engaging in IP litigation. The learning-to-contract literature posits that firms can learn from non-routine events when they engage in a contractual relationship (Lumineau et al. 2011; Mayer and Argyres 2004; Vanneste and Puranam 2010). This suggests that although learning from rare events is difficult (Christianson et al. 2009; Lampel et al. 2009; Starbuck 2009), it is possible to learn from non-routine events such as IP litigation.

Rare events often result in infrequent, ambiguous, and erratic feedback, which leads to a sense of uniqueness and diverts the firm's attention from important information cues (Christianson et al. 2009; Ocasio 1997; Rerup 2009; Salgado et al. 2002; Starbuck 2009), and potentially results in misapplied analogies (Gavetti 2011). Lack of clear feedback contributes to ambiguous interpretations of causal linkages and outcomes, which leads to biased interpretations of the learning gained from experience (Zollo 2009).

The literature on rare events reports examples of how firms can learn from rare events, if they make a deliberate effort to categorize and use the salient features of the whole category of rare events to make sense of the focal rare event (Lampel et al. 2009). Meyer (1982) found that hospitals learn how to adapt to rare environmental jolts. Rerup (2009) demonstrated that the rare event of Novo Nordisk's noncompliance with Federal Drug Agency regulation triggered deep organizational learning within the firm. Madsen (2009) analyzed how minor and major mining accidents in firms' own mines or those of proximate competitors lead to a reduced likelihood of future disasters, and Christianson et al. (2009) analyzed how a museum reorganized in response to a disaster. These examples demonstrate that rare events can facilitate organizational transformation and provide evidence that firms can learn from rare events.

We study the strategic and rare event of IP litigation, and propose that firms' that have experienced previous IP litigation can learn from their litigation experiences and apply what they have learned in future IP litigation cases. Moreover, we posit that this specific form of experiential learning helps them to win future litigation cases. Although firms may rely on external legal aid in litigations, learning has been found to transcend the client-supplier relationship (Miozzo and Grimshaw 2011), and to be created at this interface (Cohendet and Llerena 2003). We propose that some learning is likely to occur within the litigating firm, i.e. an improved understanding of the litigation process, of what information to provide to the legal counsel, how to choose and collaborate with law firms, which cases to engage in, and which cases to settle versus take to court.

IP litigation results in a ruling that states whether the plaintiff won, partially won, or lost, which is backed by a detailed explanation of the ruling pointing to the linkages the court made between the argumentation, the evidence, and the outcome

\footnotetext{
1 In 2014, 578,802 patents where applied for at the United States Patent and Trademark Office (USPTO: http://www.uspto.gov/web/offices/ac/ido/oeip/taf/us_stat.htm, assessed 6th January 2017), while U.S. courts reported only 5700 patent litigations filed in 2014 (https://www.pwc.com/us/en/forensicservices/publications/assets/2015-pwc-patent-litigation-study.pdf, assessed 6th January 2017). This indicates that approximately $1 \%$ of patents applied for ended in litigation.
} 
(see for example the analysis of rulings for biotech patents in Lin and Wang 2013). Though rulings may not offer plaintiffs complete transparency, we expect firms to learn to litigate better in future litigation cases when they have prior experience litigating and seeing how the courts rule and the reasoning behind their rulings. Thus, firms may achieve learning simply by engaging in litigation, coined here by us as learning-to-litigate. The more times a firm has engaged in litigation, the more experience the firm is likely to gather, and the better the firm should be at selecting which cases to litigate, what type of legal representation to seek, and what to do and not do during the legal process of litigation. This leads us to the first hypothesis:

H1: Firms' litigation experience is positively related to the likelihood of their receiving a positive outcome of a litigation case.

\subsection{Learning from Successful Experiences}

The learning from rare events literature generally shows that firms learn more from successful than failed rare events (Starbuck 2009). According to Ocasio (1997), positive outcomes motivate attention allocation to learning in three primary ways. First, experiencing a positive outcome enables the firms to replicate the actions taken should a similar rare event arise in the future (Starbuck 2009). Second, positive feedback facilitates learning from rare events through an increase in attention focus and confidence. Third, positive feedback further facilitates learning from rare events by encouraging firms to allocate more resources to the learning process.

In the case of firms experiencing failure, the learning literature is more ambiguous regarding the effect. Some studies suggest that failure decreases the incentive to allocate resources to learning (Ocasio 1997; Starbuck 2009), while other authors believe that firms also learn from failure (e.g. Desai 2016; Madsen and Desai 2010; Sitkin 1992; Baum and Ingram 1998; Haunschild and Sullivan 2002; Miner et al. 1999). For example, airlines that have experienced an accident are less likely to experience one in the future (Haunschild and Sullivan 2002). Automobile manufacturers with experience of having to recall cars are less likely to suffer the same experience in the future (Haunschild and Rhee 2004). Also, mining companies with first-hand or vicarious experience of negative incidents are less likely to experience an accident in the future (Madsen 2009). But learning from failure can be more difficult due to misaligned analogies, meaning that firms lack the ability to rethink situations and to search cognitively distant knowledge spaces for potential solutions to challenges (Gavetti 2011).

We suggest that in the context of IP litigation previous successful cases will allow for more learning than unsuccessful litigation cases and litigation experience in general. Successful litigation experience can facilitate learning by increasing the firm's learning intent, attention to the details of the case, and the resources allocated to the learning process. While a failure experience may also lead to some learning based on the ability to distinguish the similarity between the rare event and the broader category of events (Desai 2016), we expect more learning from successful than unsuccessful litigation. This leads us to posit that firms' relative experience in successful litigation will be positively related to future successful case outcomes. 
H2: Firms' share of previous successful, relative to the total litigation cases, is positively related to the likelihood of their receiving a positive outcome of a litigation case.

\subsection{Learning to Litigate or Learning to Navigate the Litigation System?}

Firms may learn to litigate or merely to navigate the litigation system based on past litigation experience. To distinguish between these two mechanisms, we distinguish between two distinct types of IP litigation: infringement and contract litigation. Infringement litigation involves a plaintiff and a defendant, the latter allegedly having utilized (without consent) the IP owned by the plaintiff (Heath and Petit 2005). In a case of infringement there has been no prior contract negotiated between the plaintiff and defendant, and the plaintiff has not granted the defendant access to its IP. It frequently involves parties that are relatively unknown to one another. An infringement case typically is initiated when the alleged infringing product is spotted in the market by sales personnel or detectives hired to conduct market surveillance (Alkaersig et al. 2015). After their identification, samples of the allegedly infringing product are bought to serve as evidence. This is followed by a cease and desist letter from the plaintiff to the defendant, stating that the defendant must stop infringing on its IP and destroy the infringing products by a certain date or legal proceedings will be initiated (Fisher 2000). If the defendant continues the allegedly illegal production, distribution, and/or sale of the infringing product, the plaintiff can follow through with its threat and file a lawsuit to pursue the matter.

Contract based IP litigation is very different. In contract litigation cases, a prior contract has been negotiated, outlining the conditions for the relationship or license, what will transpire should the contract conditions not be complied with, and the conditions under which the contract will be terminated. Contracts between firms that include IP are likely to be related to strategic alliances, consortia, licensing, outsourcing, or supplying (Anand and Khanna 2000). Typically, firms engage in contractual exchanges to share knowledge, products, services, and technologies, resulting in their improved innovation and financial performance (Lane and Lubatkin 1998; Mowery et al. 1996). Extant literature has demonstrated that firms may learn to contract (Argyres and Mayer 2007; Bercovitz and Tyler 2014). Firms with experience from contract litigation therefore have opportunity to utilize this experience to improve their contracting as well as to increase their likelihood of winning contract litigation cases.

If firms merely learn to navigate the litigation process and legal system, then the fit between the type of cases from which they have previously gathered experience and the current case type should not influence the likelihood of a positive outcome of the current case. But, if firms learn to litigate and not merely to navigate the litigation system, the effect of experience will depend on the fit between the experience and the current litigation type: If firms learn to litigate, they will benefit more from experience from the same case type as their current litigation case. Following this logic, we propose two hypotheses, which link experience from infringement litigation to the outcomes of infringement cases, and experience from contract litigation to the outcomes of contract cases: 
H3a: Firms' experience from infringement litigation is positively related to the likelihood of their receiving a positive outcome of an infringement litigation case.

H3b: Firms' experience from contract litigation is positively related to the likelihood of their receiving a positive outcome of a contract litigation case.

\section{Methods}

\subsection{Sample}

We test the hypotheses using data on litigation cases in China between 2001 and 2009. We seek to avoid left truncation by using observations from 2001 to 2004 to create a baseline of organizational experience and focus our analyses on the period from 2005 to 2009 . These longitudinal data allow us to observe involvement of 4786 plaintiffs and 4668 defendants in 10,211 court cases (9718 infringement cases and 457 contract cases) in 94 major IP courts, in 35 Chinese cities representing all six regions of China. Our data are organized at the case level, with each observation representing a firm acting as the plaintiff in a court case. For each case, we focus on the plaintiff firm. The plaintiff firm is the party that initiates the court case, and thereby, demonstrates the greatest agency. Since the aim is to understand how experience affects litigation outcomes, we are interested in those firms with the most agency, i.e. plaintiff firms.

Our data are from CIELA, a private service provider delivering statistical analysis of IP litigation cases in China to clients. CIELA is part of the London based IP specialist consultancy group Rouse \& Co International LLP, and gathers published IP judgments in China. CIELA has expats managing its operations in China, with years of experience of preparing foreign firms' court strategies and briefs for IP litigations in China. The data are collected through CIELA affiliated employees paying regular and frequent visits to all major IP courts in China and manually recording cases and rulings. CIELA issues detailed instructions for its local employees on how to collect the data from the courts, and conduct quality control of the data. The business model of CIELA rests on the reliability of the data.

Only a proportion of disputes end up in court (Lumineau and Oxley 2012), thus we can study only those cases where organizations have been unable to or not interested in reaching a private settlement. We rejected opportunities to purchase firm level balance sheet data, due to concerns that their quality might be questionable.

\subsection{Appropriateness of the Context}

It is appropriate to study learning dynamics in IP litigation with a focus on China for two main reasons. First, Chinese firms seldom apply for IP outside of China, and consequently, are unlikely to have learned from bringing IP cases to court in foreign countries. Therefore, studying the Chinese court system allows us to observe learning effects in a system largely unpolluted by external experience. For example, U.S. patents granted to Chinese firms in 2013 represent only $4 \%$ of the patents 
registered by Chinese firms in China, and only $2 \%$ of U.S. patents granted (Alcacer et al. 2015). Second, Chinese firms had few opportunities to litigate IP in China prior to the study period ( $\mathrm{Xi}$ et al. 2009). They are therefore unlikely to have litigation experience not observed in our data. During the Cultural Revolution (1966-1976) IP laws were abandoned in China. Although Deng Xiao Peng introduced the Open Door policy in 1979, and initiated an IP legal framework, it was not until China entered the World Trade Organization in 2001 and initiated its compliance with the Trade Related Aspects of Intellectual Property Rights that the IP system in China was developed.

\subsection{Measures}

\subsubsection{Dependent Variable}

Our dependent variable is Positive outcome. The verdicts in litigation fall into three categories: the plaintiff won, the plaintiff partially won, or the plaintiff lost the litigation. We combined, won and partially won, into one category to construct our positive outcome measure. Conducting background interviews with field experts, we learned that for various reasons, firms do not necessarily litigate with the intention of an outright win, and that a partial win is also often considered as a positive outcome, we measure this as a binary variable where 1 denotes a positive outcome for the plaintiff, and 0 denotes a negative outcome for the plaintiff. We conduct robustness checks with win as outcome variable.

\subsubsection{Explanatory Variables}

The variable Experience (ln) measures plaintiffs' experience with the Chinese court system. For this measure, we take each plaintiff firm and log the value of the number of cases the firm has been involved in as either plaintiff or defendant in the three years before the focal case. The choice of a three-year window ensures that we capture experience, but also respects that this is a rapidly developing system where experience becomes outdated. The variable Share Previous Positive Outcomes measures plaintiffs' experience of positive outcomes. We calculate this variable as the share of positive outcomes the plaintiff has achieved across all litigations in the three years before the focal case. In the split sample models we distinguish between infringement and contract cases and distinguish between experience from different case types with the variables Infringement experience $(\ln )$ and Contract experience (ln).

\subsubsection{Control Variables}

We control for type of IP considered in the case: patent, trademark, copyright, and unfair competition. Each of the four variables is constructed as a dummy variable (IPR types dummies). We use copyright as the reference sample, and report the other three. We control for how often the plaintiff acts as plaintiff versus defendant with the variable Share plaintiff. We control for the nationality of the plaintiff firm with 
the variable Foreign firm, where the firm is coded 0 if it is a Chinese firm and 1 if it is a foreign firm. Chinese firms constitute the reference group for this measure. Finally, we include the city in which the court was located (city dummies) and year dummies in all the estimations, but due to space constraints we only report effects for Beijing and Shanghai in the models in Tables 2 and 3.

The defendant's experience can also potentially affect the case outcome. To control for the effect of defendant's experience we include three variables. Defendant Experience (ln) measured as the logged number of cases the defendant has litigated in the previous three years as either plaintiff or defendant; Defendant contract experience (ln) and Defendant infringement experience (ln).

\subsection{Methodology}

Our dependent variable takes the values 0 and 1; consequently, we need to choose between estimating a logit or a probit model, and we chose a logit specification. Heteroskedasticity can affect the reliability of the results, and we address this issue using two estimation strategies. First, we estimate robust standard errors, second, we address the fact that outcomes can co-vary across cases based on both plaintiff and defendant. To control for clustering of observations on both plaintiff and defendant in one model we use the approach developed by Cameron, Gelbach, and Miller (2011), which allows for clustering of standard errors based on more than one variable. The approach is used in Kleinbaum, Stuart, and Tushman (2013) to study e-mail exchanges within an organization, and in Dahlander and McFarland (2013) to study faculty collaborations at Stanford. The model predicting the probability of a successful case outcome can be specified as:

\section{1. $\operatorname{Pr}($ Positive outcome $=1)=\mathrm{le}, \mathrm{s}, \mathrm{c}, \boldsymbol{\beta}$}

where e denotes the firm's previous experience and s denotes the firm's share of previous successful litigations, and $\mathrm{c}$ is a vector of the controls. We report results for the full sample of 10,211 litigation cases for models testing hypotheses 1 and 2 . And for the full sample as well as for the 9718 infringement cases and for the 457 contract cases separately for the models testing hypotheses $3 \mathrm{a}$ and $3 \mathrm{~b}$. This split sample estimation strategy is motivated by hypothesis $3 \mathrm{a}$ and $3 \mathrm{~b}$, which point to that different types of experience is likely to have different relationships to outcomes in contract and infringement litigations respectively.

\section{Results}

Fig. 1 depicts the distribution of litigation cases across years, and Table 1 shows the descriptive statistics for the full sample. On average, there is a $76.6 \%$ likelihood of the plaintiff firms experiencing a positive outcome (25\% likelihood of plaintiffs winning the litigation). From Table 1 it is evident that about half of the plaintiff firms have previous experience with either infringement or contract litigation but that only a third of the defendant firms had previous litigation experience. The plaintiff firms in our sample very rarely act as defendants in the cases in which they were involved 


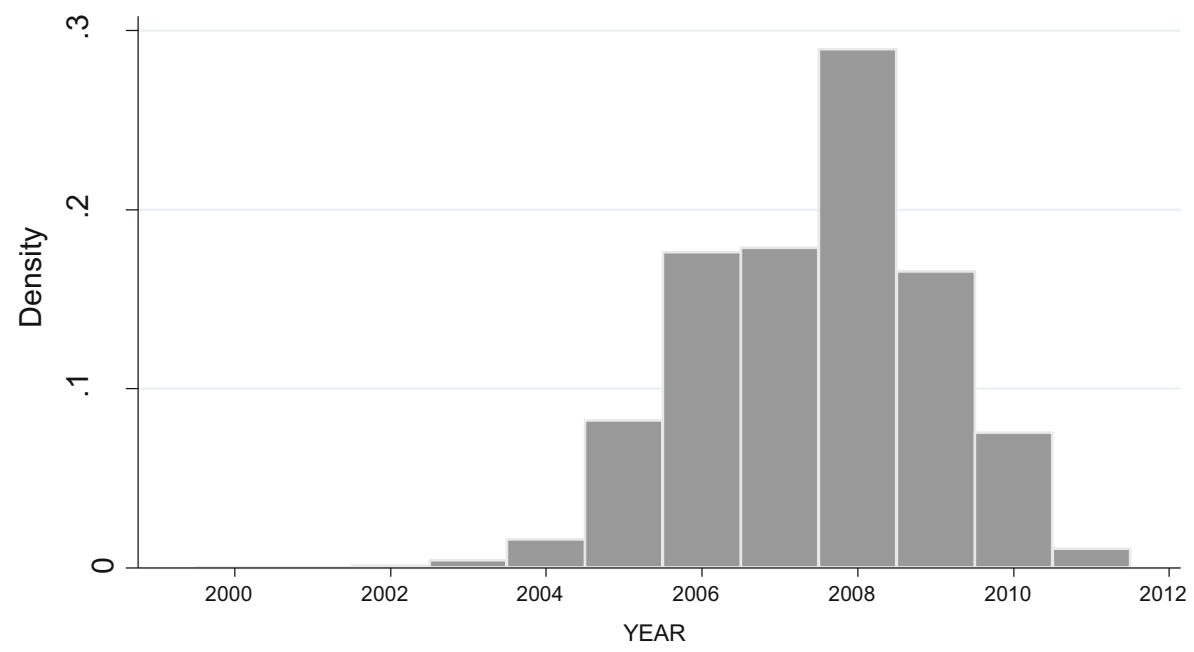

Fig. 1 Distribution of IP litigation court cases per year

(Share plaintiff is $98 \%$ ). Only $5 \%$ of the cases are contract cases. Finally, $9 \%$ of the plaintiffs are foreign firms, and more than half of the firms litigated their cases in either Beijing (42.5\%) or Shanghai (10.9\%).

Table 1 also shows the pairwise correlations of the dependent, independent, and control variables for the full sample. There is the expected high correlation between previous successful litigation and litigation experience (ln) and we address this issue in our estimation strategy. There is a negative correlation between the experience of defendants and the plaintiff receiving a positive outcome that is interesting.

Tables 2 and 3 depicts the results of the models testing our hypotheses. Model 1in Table 2 is the baseline model for the full sample and shows the variance explained by the control variables. Table 2, Model 2 includes the plaintiff's and defendant's experience in the Chinese litigation system. The defendant's experience is not significant, but the plaintiff's experience has a positively significant relationship with a positive outcome for the plaintiff. This finding supports hypothesis 1 .

Hypothesis 2 is tested in Table 2, in Model 3, which included both plaintiffs' experience with the litigation system and the share of previous cases in which the plaintiff received a positive outcome. The share of previous positive outcomes is positively related to the likelihood that plaintiffs receive positive outcome in the current litigation, but when plaintiff's share of previous positive outcomes is included in the model the relation between litigation experience in general and the likelihood of receiving a positive outcome is no longer significant. This indicates that the outcome of previous cases is more important than simply having litigation experience. The control variables in Model 3 in Table 2 shows that foreign plaintiffs and plaintiffs litigating in Shanghai have higher likelihood of receiving a positive outcome. Litigation of some IPR types also have significantly higher or lower likelihood of receiving a positive outcome.

Hypothesis $3 \mathrm{a}$ and $3 \mathrm{~b}$ on the specific relationship between experience from infringement versus contract litigation and plaintiffs' positive outcomes in infringe- 


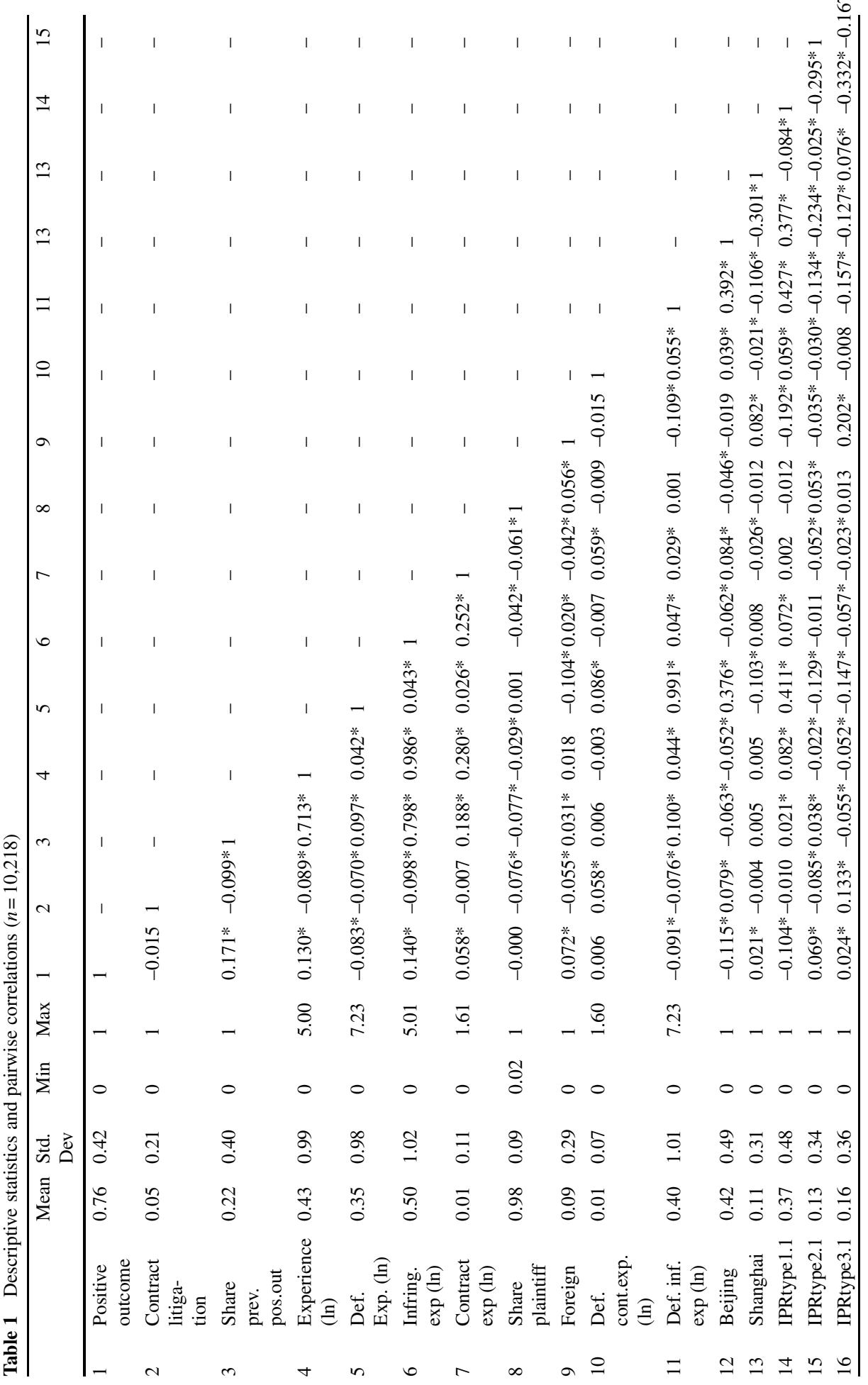


Table 2 Plaintiffs' likelihood of obtaining a positive outcome

\begin{tabular}{|c|c|c|c|}
\hline & $\begin{array}{l}\text { Model } 1 \\
\text { Controls }\end{array}$ & $\begin{array}{l}\text { Model } 2 \\
\text { Litigation experience }\end{array}$ & $\begin{array}{l}\text { Model } 3 \\
\text { Litigation experience \& share wins }\end{array}$ \\
\hline \multirow{2}{*}{$\begin{array}{l}\text { Share prev. } \\
\text { win }\end{array}$} & - & - & $1.095^{* * *}$ \\
\hline & - & - & {$[0.242]$} \\
\hline \multirow{2}{*}{$\begin{array}{l}\text { Experience } \\
(\ln )\end{array}$} & - & $0.350 * * *$ & 0.013 \\
\hline & - & {$[0.111]$} & {$[0.102]$} \\
\hline \multirow{2}{*}{$\begin{array}{l}\text { Def. } \\
\text { Experience } \\
(\ln )\end{array}$} & - & -0.058 & $-0.106^{*}$ \\
\hline & - & {$[0.070]$} & {$[0.060]$} \\
\hline \multirow{2}{*}{$\begin{array}{l}\text { Share } \\
\text { plaintiff }\end{array}$} & -0.287 & -0.121 & 0.175 \\
\hline & [0.439] & [0.405] & {$[0.373]$} \\
\hline \multirow[t]{2}{*}{ Foreign } & $0.804 * * *$ & $0.726 * * *$ & $0.686^{* * *}$ \\
\hline & [0.174] & {$[0.178]$} & [0.178] \\
\hline \multirow[t]{2}{*}{ Beijing } & 0.040 & 0.135 & 0.199 \\
\hline & [0.179] & {$[0.188]$} & [0.183] \\
\hline \multirow[t]{2}{*}{ Shanghai } & $0.416^{*}$ & $0.395^{*}$ & $0.431 * *$ \\
\hline & [0.227] & {$[0.215]$} & {$[0.217]$} \\
\hline \multirow[t]{2}{*}{ IPRtype1_1 } & 0.144 & 0.067 & 0.091 \\
\hline & [0.181] & [0.201] & [0.192] \\
\hline \multirow[t]{2}{*}{ IPRtype1_2 } & $1.617 * * *$ & $1.314^{* * * *}$ & $1.257 * * *$ \\
\hline & {$[0.272]$} & {$[0.267]$} & [0.269] \\
\hline \multirow[t]{2}{*}{ IPRtype1_3 } & 0.149 & 0.153 & 0.201 \\
\hline & [0.317] & {$[0.317]$} & [0.318] \\
\hline \multirow[t]{2}{*}{ IPRtype2_1 } & $0.427 * *$ & $0.390 * *$ & $0.352 *$ \\
\hline & {$[0.201]$} & [0.195] & [0.193] \\
\hline \multirow[t]{2}{*}{ IPRtype2_2 } & $-0.468 * *$ & $-0.496^{* *}$ & $-0.518^{* * *}$ \\
\hline & [0.204] & [0.199] & {$[0.196]$} \\
\hline \multirow[t]{2}{*}{ IPRtype2_3 } & -0.200 & -0.196 & -0.233 \\
\hline & [0.195] & [0.193] & [0.191] \\
\hline \multirow[t]{2}{*}{ IPRtype3_1 } & 0.132 & 0.132 & 0.147 \\
\hline & [0.167] & [0.168] & [0.168] \\
\hline \multirow[t]{2}{*}{ IPRtype4_1 } & 0.025 & 0.028 & 0.030 \\
\hline & {$[0.373]$} & {$[0.374]$} & [0.387] \\
\hline \multirow[t]{2}{*}{ IPRtype4_2 } & $0.723 * *$ & $0.738 * *$ & $0.779 * * *$ \\
\hline & [0.290] & {$[0.290]$} & [0.290] \\
\hline \multirow[t]{2}{*}{ IPRtype4_3 } & 0.295 & 0.327 & $0.359 *$ \\
\hline & [0.207] & [0.205] & {$[0.205]$} \\
\hline \multirow[t]{2}{*}{ IPRtype4_4 } & -0.079 & -0.043 & -0.002 \\
\hline & [0.247] & [0.246] & [0.246] \\
\hline \multirow[t]{2}{*}{ Constant } & $1.356^{* * * *}$ & $1.069 * *$ & 0.630 \\
\hline & [0.519] & {$[0.490]$} & [0.464] \\
\hline Pseudo LL & $-5,181.803$ & $-5,123.823$ & $-5,073.996$ \\
\hline No of Obs & 10,211 & 10,211 & 10,211 \\
\hline
\end{tabular}

$* p<0.1, * * p<0.05, * * * p<0.01$ 


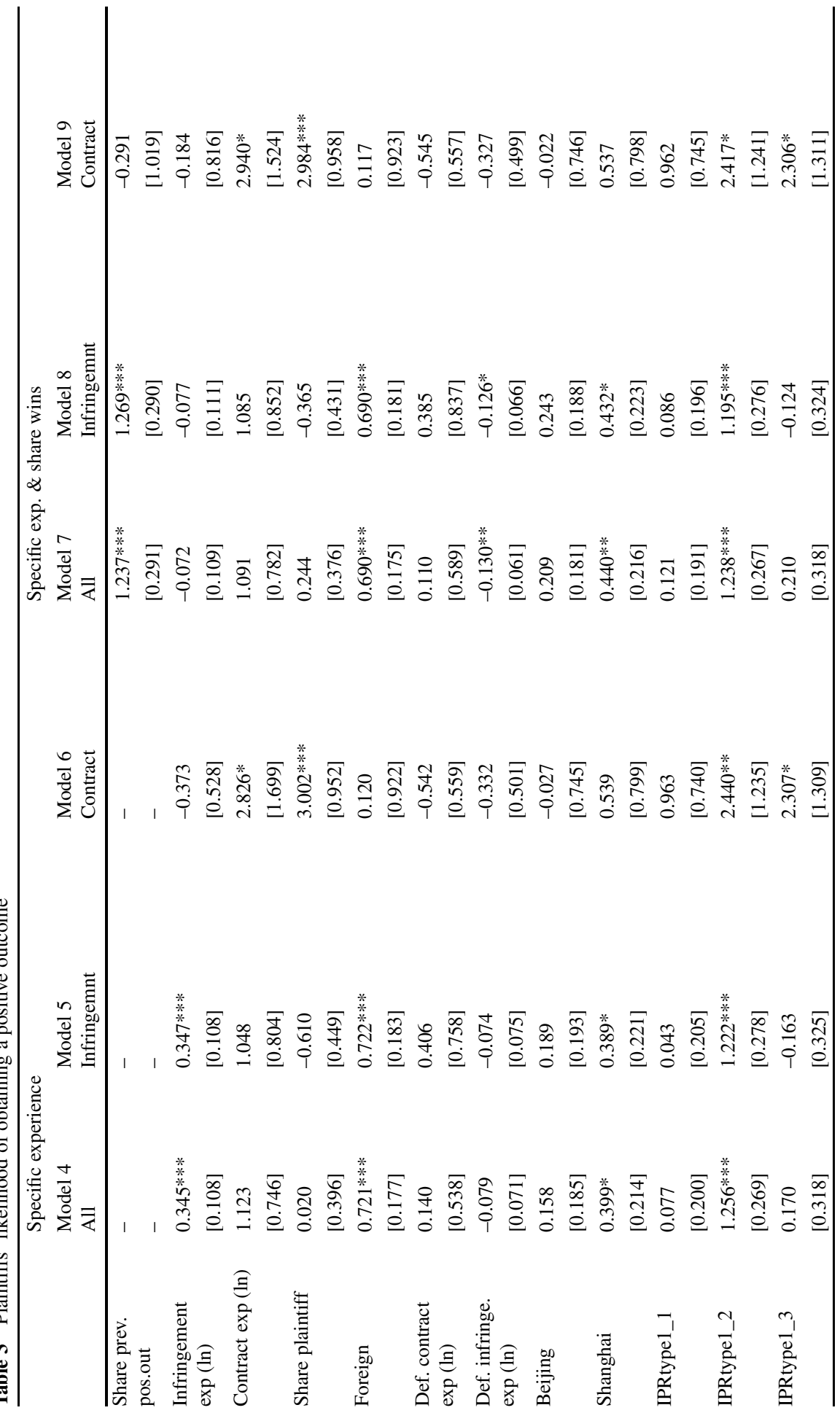




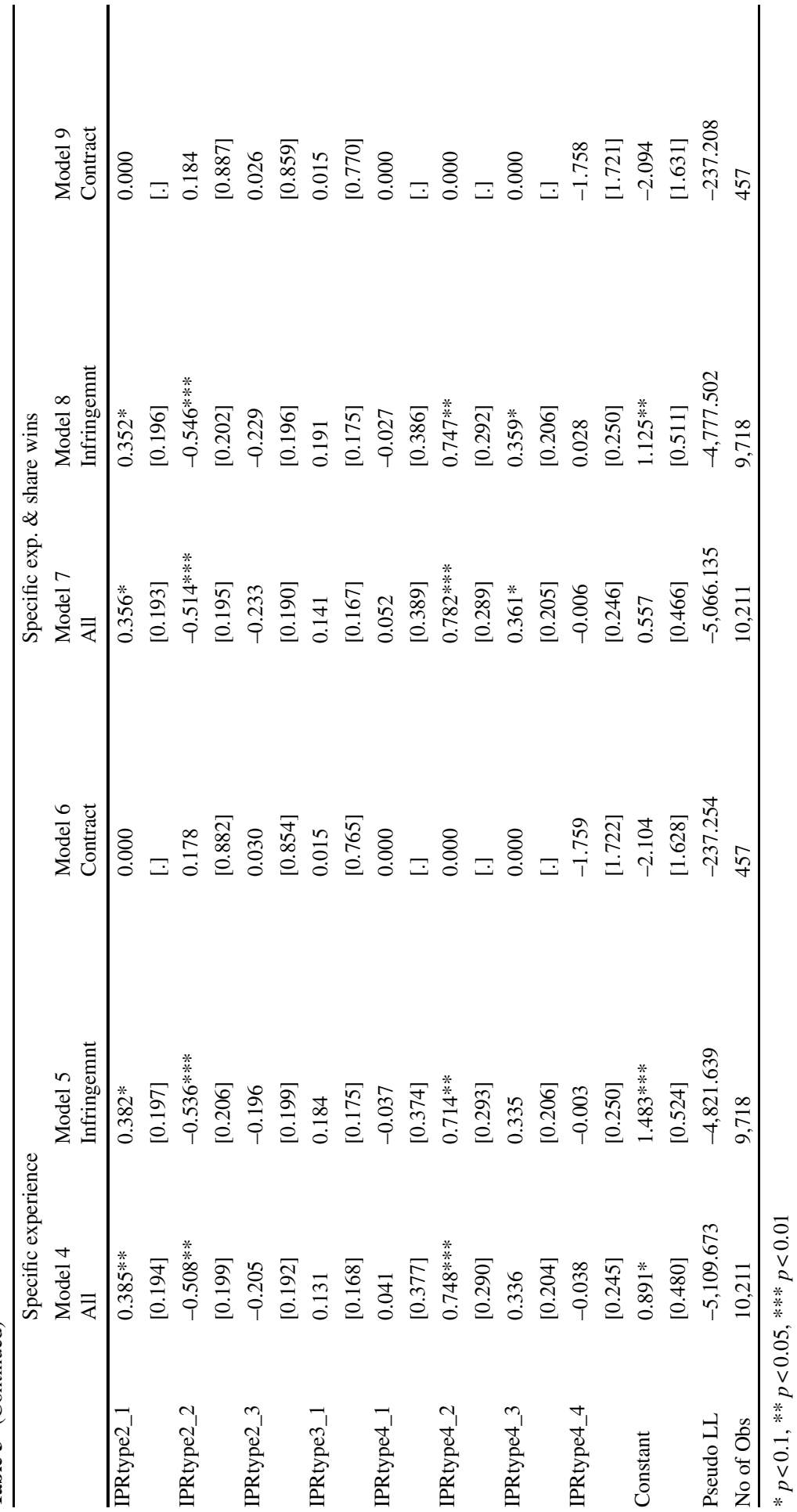


ment versus contract litigations are tested in Table 3, Models 4, 5 and 6, and Models 7, 8 and 9. Model 4 includes the full sample, while Models 5 and 6 distinguish between plaintiffs' experience with infringement litigation cases (Model 5) and experience with contract litigation cases (Model 6). Model 7, 8 and 9, keeps this distinction and adds the variable measuring plaintiffs' share of previous positive outcomes. The results in Model 5 confirm the relationship hypothesized in H3a: Experience from infringement litigation has a positive relationship with plaintiffs' likelihood of receiving a positive outcome in infringement litigation, but the relationship seizes to be positive when plaintiff's share of previous positive outcomes is added in Model 8. Neither Model 5 nor Model 8 shows a significant relationship between experience from contract litigation and positive outcome in infringement litigation. Hypothesis $3 \mathrm{a}$ is therefore partly supported by the data: Firms' experience from infringement litigation is positively related to the likelihood of their receiving a positive outcome from an infringement litigation case, but only when their share of previous positive outcomes is not included in the model. Plaintiffs' share of previous positive outcomes has a positive relationship with their likelihood of a positive outcome. In model 5 and 8 foreign plaintiffs and plaintiffs litigating in Shanghai have a significantly higher likelihood of a positive outcome in infringement litigation cases, while Model 8 show a negative relationship between defendants' experience with infringement litigation and the likelihood that the plaintiff receives a positive outcome. Litigation of some IPR types also have significantly higher or lower likelihood of receiving a positive outcome.

Hypothesis $3 b$ is tested in model 6 and 9. Experience with contract litigation has a positive relationship with plaintiffs' likelihood of receiving a positive outcome in contract litigation cases in model 6, and including the plaintiff's share of previous positive outcomes in model 9 does not alter the relationship. The relationship is only significant at the 0.1 level in model 9 (two-sided test), but due to the small sample of contract litigation cases we accept this as support for hypothesis $3 \mathrm{~b}$. Interestingly, the control variable measuring the share of previous cases in which the plaintiff has acted as plaintiff and not defendant has a positive relationship with the likelihood of the plaintiff receiving a positive outcome. Litigation of some IPR types also have significantly higher or lower likelihood of receiving a positive outcome.

While data limitations (small numbers) do not allow us to be conclusive, this seems to suggest that in our sample of firms, those involved in infringement litigation learned more from previous successful litigation cases than from their general litigation experience or specific experience with infringement litigation. While those involved in contract litigation seem to learn more from prior contract litigations than from infringement litigation or from previous positive outcomes. They may have learned how to engage in contractual relationships regardless of the positive or negative outcomes of previous litigations-i.e., they learned-to-contract.

Fig. 2 reports the marginal effects of explanatory variables in the Table 2, Model 3, Table 3 Models 5 and 9. For each sample (all, plaintiffs in infringement litigations, and plaintiffs in contract litigations) we plotted marginal effects for the model most interesting in terms of significant key variables. The plot in Fig. 2a shows marginal effects of plaintiffs' share of previously positive outcomes from Model 3, testing hypothesis 2 . The plot shows an almost linear relationship between the marginal 
Fig. 2 Marginal plots for key variables "Share of previous cases with positive outcome", "Experience with infringement litigation", and "Experience with contract litigation" estimated in model 3, 5 and 9 respectively. a (all). Effect of share of previous cases with positive outcome for likelihood of obtaining a positive outcome in infringement cases (based on model 3). b (infringement). Effect of experience with infringement litigation for likelihood of obtaining a positive outcome in infringement cases (based on model 5). c (contract). Effect of experience with contract litigation for likelihood of obtaining a positive outcome in contract cases (based on model 9). Note: Estimates may vary slightly from those reported in models 3,5 and 9 , as margins are calculated for the corresponding models only clustered by plaintiff
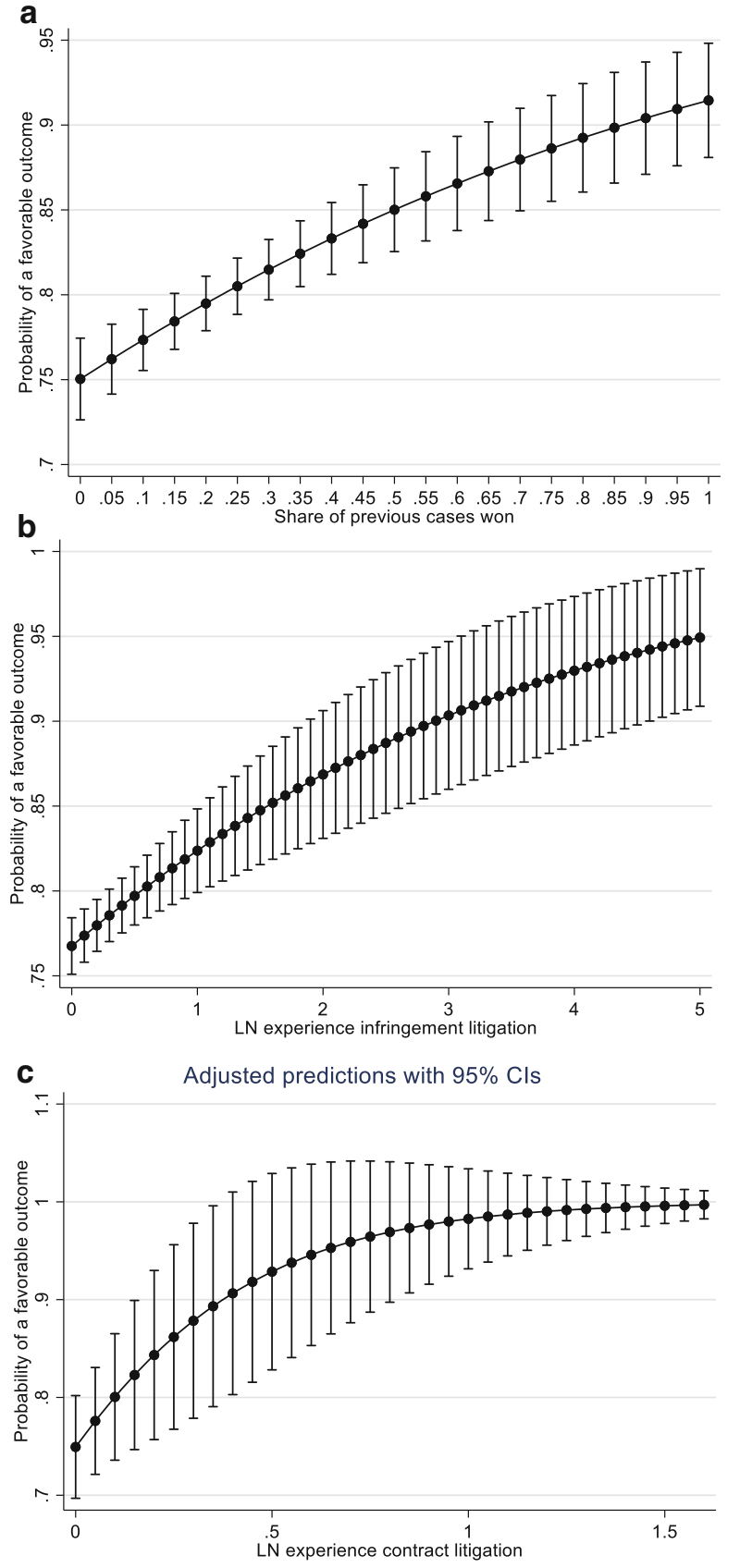

effect of plaintiffs' share of previous positive outcomes and the likelihood of a positive outcome. The plot in Fig. $2 b$ shows the marginal effect of experience from infringement litigation as estimated in Model 5 testing hypothesis $3 \mathrm{a}$. In this model 
experience from infringement litigation is positively related to the likelihood of a positive outcome of the focal case, though the effect turns insignificant in the models that include the share of previous successful litigations. Plaintiffs' likelihood of a positive outcome increases almost linearly across the distribution of experience with infringement litigation, and for very high levels of experience, the plaintiff has a very high likelihood of a positive outcome. The plot in Fig. 2c shows marginal effects of experience from contract litigation for the likelihood of plaintiffs receiving a positive outcome in a contract litigation. This plot follows a different distribution than those in Fig. 2a and b. The marginal effect raises rapidly and then flattens out. It is challenging to interpret this distribution, due to the few plaintiffs' in contract cases that hold experience from more than one previous contract litigation and the fact that all plaintiffs' having multiple contract cases received positive outcomes. None the less it is interesting to speculate as to why learning appeared to be so quick in contract litigation relative to infringement litigation. We will return to this topic in the discussion.

Because the effect of experience with litigation described in hypothesis 1 does not remain significant when the share of previous litigations won is included in the models, and because the tests of hypothesis $3 \mathrm{a}$ and $3 \mathrm{~b}$ clearly demonstrates that the effect of litigation experience depends on litigation type (infringement or contract) we do not present a plot illustrating hypothesis 1 .

To check the robustness of our findings, we rerun our main models with different specifications. We test if our measurement of the dependent variable influences the estimated values of our key variables by rerunning the models with win as dependent variable (compared to the combination of win and partial win in our main models). Interestingly, we find that this narrower focus on completely winning litigations increases the importance of the defendants' experience. In this robustness check defendants' experience, defendants' experience with infringement litigation, defendants' experience with contract litigation, and defendants' share of previously won cases is an almost perfect mirror image of the effects of plaintiffs' experience in our main models: Defendants' experience has a negative relationship with the plaintiff's likelihood of completely winning litigations. We address this interesting distinction in the discussion section. We also estimate models for the split samples mirroring Models 1, 2 and 3 in Table 2, and the results confirm the findings in the split sample models reported in Table 3.

\section{Discussion and Conclusion}

This paper analyzed how litigation experience and the share of previous positive litigation experience are related to the likelihood of receiving a positive outcome in a focal litigation case. Our findings suggest that plaintiff firms in IP litigations that have more litigation experience are more likely to receive a positive outcome in a current litigation case, but also that relatively more successful litigation experience is even more important than simply litigation experience. Furthermore, we found different effects for the two types of litigations: infringement and contract litigation cases. Plaintiffs in infringement cases have a higher likelihood of receiving a positive 
outcome, if they have greater experience with litigation in general or with infringement litigation, but both effects are insignificant, when the model also include their share of previous positive litigation outcomes. Plaintiffs may draw upon previous experiences that resulted in a positive outcome and use this experience to increase their likelihood of a positive outcome in a focal case. Pure exposure to the litigation system is not as related to a positive outcome in a focal case as prior successful litigation. For plaintiffs involved in contract cases the findings reveal that experience in general litigation and experience from infringement litigation cases are unrelated, instead the specific experience of prior contract litigation is significantly related to the likelihood of a positive outcome. This suggests that plaintiffs learn to litigate and do not merely learn to navigate the litigation system.

Our robustness tests showcased an interesting distinction between how plaintiffs' versus defendants' experience influenced successful outcomes (winning versus partially winning). Interestingly, while the plaintiffs' experiences had significant effects for the likelihood of them receiving a positive outcome, it was the defendants' experiences that had a significant effect on the likelihood of the plaintiff winning the case. This indicates, that plaintiffs' own experience may help them not to lose a litigation, but the likelihood of the plaintiff actually winning is more related to the experience of the opponent, namely the defendant. This interesting distinction points to learning effects on both sides of the court room.

Plaintiffs may be dissatisfied with court rulings even if they win completely or partially, as a full winner may consider the size of the damages awarded unacceptable, and plaintiffs partially winning a case may decide to appeal in the hope of a complete win or receipt of higher damages. $11 \%$ of contract cases and $16 \%$ of infringement cases in our sample were appealed. Not surprisingly a main factor influencing whether or not a plaintiff appeals is the outcome of the case: $53 \%$ of plaintiffs losing a litigation choose to appeal the ruling, while this is only the case for $2 \%$ of plaintiffs partly winning and $16 \%$ of plaintiffs completely winning their litigation cases. It is not surprising that the loosing plaintiffs are more likely to appeal the verdict, but that the share of appeals is higher for plaintiffs winning their litigations than for plaintiffs only partially winning is interesting and points to the complex nature of these rulings. Plaintiffs that win may be dissatisfied with the damages, while plaintiffs that partly win may be relieved not to lose.

A simple correlation shows that plaintiffs with more experience, and plaintiffs that act as plaintiffs in a high share of the cases they are involved in are less likely to appeal (the correlation coefficient for litigation experience $=-0.08$ and for share plaintiff $=-0.1)$. It is not possible within the framework of this paper to assess whether the decision to appeal or not is the optimal strategy for these experienced plaintiffs, but these descriptive statistics indicate that as plaintiffs learn to litigate they may also learn when to give up and accept a ruling.

Our findings contribute to the organizational learning literature with the notion, that organizations can learn from non-routine events. The learning to contract literature has demonstrated that organizations can learn to develop their contracting from repeated interaction with a contacting partner, and the results of this study push the boundaries for our understanding of organizations ability to learn from rare event even further: Even organizations that only engage in IP infringement litigation 
infrequently may utilize experiences from previous infringement cases, especially previous successful cases, to increase their likelihood of receiving a positive outcome.

The study also makes two contributions to the literature on management of IP and litigation. First, we propose a theoretical lens, which we coined as "learning to litigate", that can be applied in future studies of litigation. This literature tends to focus on observed cross-sectional data on technology and type of plaintiff for determining why firms engage in litigation (e.g. Agarwal et al. 2009; Lanjouw and Schankerman 2001; Polidoro and Toh 2011; Somaya 2003), to predict litigation outcomes (Janicke and Ren 2006; Moore 2003). Future research could leverage the idea that firms may learn to litigate, to explore new aspects of firm behavior in litigation cases. Second, extant litigation research centers mainly on U.S. litigations (Janicke and Ren 2006; Moore 2003), and more recently, European litigations (Graham and Van Zeebroeck 2014; Schliesser 2015). Litigation in China has been rather overlooked despite the increase in IP applications and IP litigation in China (Alcacer et al. 2015), and its significantly different local patent system (see, e.g., Van Pottelsberghe de la Potterie 2011 on the patent examination system).

As is the case with all research, this study has some limitations, which suggest directions for future research. First, because our study is limited to IP litigation in China, there could be concerns over the generalizability of our results. Emerging economies are characterized by weak legal and regulatory environments, which applies also to China (Zhao 2006). However, many countries across the world are considered to be emerging economies with weak legal and regulatory systems. This suggests that our findings might be generalizable more to these emerging economies than to developed economies. Thus, we encourage future research to replicate our study in developed economies' litigation systems and also to investigate whether firms may also learn to litigate IP infringement cases based on experiences in developed economies with established legal systems.

Our study does not include details of the monetary amounts of the damages awarded to those that won or partially won, nor does our data provide information on the extent to which firms relied on external law firms. Future research could consider more fine-grained data, and elaborate on whether inhouse versus external competences may be a boundary condition for firms' opportunities to learn from litigation experience.

There are several additional research directions that warrant discussion. First, future research should further assess other contingencies that may affect the level of learning from litigation. For example, do larger monetary awards motivate firms to pay more attention to the verdict and apply more resources with the intent to learn from litigation? Second, research has shown that learning from related experiences rather than more instances of a single type of experience might lead to a greater rate of learning (Schilling et al. 2003). Thus, it would be interesting to evaluate if the learning from IP infringement litigation is enhanced by litigating a variety of IP types (patents, industrial designs, copyrights, and trademarks) versus consistently litigating one type. Third, this study only focuses on how litigation experience affects litigation outcomes, without showing how settlements out of court may influence litigation outcomes. It would be very informative if future research could explore 
how firms determine which cases to litigate and which cases to settle out of court and how these choices influence one another. Studies could also look at how a single firm or set of firms transfer their litigation learning across defendants and countries.

Acknowledgements The authors would like to thank Editor-in-Chief Alfred Wagenhofer, associate editor Tobias Kretschmer, and the two anonymous reviewers for constructive feedback throughout the review process. We also thank CIELA for generously sharing their data with us.

Open Access This article is licensed under a Creative Commons Attribution 4.0 International License, which permits use, sharing, adaptation, distribution and reproduction in any medium or format, as long as you give appropriate credit to the original author(s) and the source, provide a link to the Creative Commons licence, and indicate if changes were made. The images or other third party material in this article are included in the article's Creative Commons licence, unless indicated otherwise in a credit line to the material. If material is not included in the article's Creative Commons licence and your intended use is not permitted by statutory regulation or exceeds the permitted use, you will need to obtain permission directly from the copyright holder. To view a copy of this licence, visit http://creativecommons.org/licenses/by/4.0/.

\section{References}

Agarwal, R., M. Ganco, and R.H. Ziedonis. 2009. Reputations for toughness in patent enforcement: implications for knowledge Spillovers via inventor mobility. Strategic Management Journal 30:1349-1374.

Alcacer, J., K. Beukel, and B. Cassiman. 2015. Capturing value from IP in a global environment. Center for Global Enterprise, NYU Stern. http://thecge.net/wp-content/uploads/2016/01/Capturing-Valuefrrm-IP-in-a-Global-Enviroment.pdf.

Alkaersig, L., K. Beukel, and T. Reichstein. 2015. Intellectual property rights management: rookies, dealers, strategists and strategic dealers. Palgrave Macmillan.

Anand, B.N., and T. Khanna. 2000. The structure of licensing contracts. Journal of Industrial Economics 48:103-135.

Argote, L. 1999. Organizational learning: creating, retaining and transferring knowledge. Boston: Kluwer Academic Publishers.

Argyres, N.S., and K.J. Mayer. 2007. Contract design as a firm capability: an integration of learning and transaction cost perspectives. Academy of Management Review 32:1060-1077.

Baum, J.A.C., and P. Ingram. 1998. Survival-enhancing learning in the Manhattan hotel industry, 1898-1980. Management Science 44:996-1016.

Bercovitz, J., and B.B. Tyler. 2014. Who I am and how I contract: the effect of contractors" roles on the evolution of contract structure in university-industry research agreements. Organization Science 25:1840-1859.

Cameron, A.C., J.B. Gelbach, and D.L. Miller. 2011. Robust inference with multiway clustering. Journal of Business \& Economic Statistics 29:238-249.

Christianson, M.K., M.T. Farkas, K.M. Sutcliffe, and K.E. Weick. 2009. Learning through rare events: significant interruptions at the Baltimore \& Ohio railroad museum. Organization Science 20:846-860.

Cohendet, P., and P. Llerena. 2003. Routines and incentives: the role of communities in the firm. Industrial and Corporate Change 12:271-297.

Cyert, R.M., and J.G. March. 1963. A behavioral theory of the firm. Englewood Cliffs: Prentice-Hall.

Dahlander, L., and D.A. McFarland. 2013. Ties that last: tie formation and persistence in research collaborations over time. Administrative Science Quarterly 58:69-110.

Desai, V. 2016. Learning to learn from failures: the impact of operating experience on railroad accident responses. Industrial and Corporate Change 25:199-226.

Fisher, D.E. 2000. Managing the risks of commercializing new technology. IEEE Xplore.

Gavetti, G. 2011. The new psychology of strategic leadership. Harvard Business Review 89:118-125.

Graham, S., and N. Van Zeebroeck. 2014. Comparing patent litigation across Europe: a first look. Stanford Technology Law Review 17:655-708.

Haunschild, P.R., and M. Rhee. 2004. The role of volition in organizational learning: the case of automotive product recalls. Management Science 50:1545-1560.

Haunschild, P.R., and B.N. Sullivan. 2002. Learning from complexity: effects of prior accidents and incidents on airlines' learning. Administrative Science Quarterly 47:609-643. 
Heath, C., and L. Petit. 2005. Patent enforcement worldwide: a survey of 15 countries. Writings in honour of Dieter Stauder. Oxford: Hart Publishing.

Janicke, P., and L. Ren. 2006. Who wins patent infringement cases. Aipla Quarterly Journal 34:1.

Kleinbaum, A.M., T.E. Stuart, and M.L. Tushman. 2013. Discretion within constraint: homophily and structure in a formal organization. Organization Science 24:1316-1357.

Lampel, J., J. Shamsie, and Z. Shapira. 2009. Experiencing the improbable: rare events and organizational learning. Organization Science 20:835-845.

Lane, P.J., and M. Lubatkin. 1998. Relative absorptive capacity and interorganizational learning. Strategic Management Journal 19:461-477.

Lanjouw, J., and J. Lerner. 1998. The enforcement of intellectual property rights: a survey of the empirical literature. Annales d'Economie et de Statistique 49-50:223-246.

Lanjouw, J.O., and M. Schankerman. 2001. Characteristics of patent litigation: a window on competition. Rand Journal of Economics 32:129-151.

Lin, F.Y., and S.J. Wang. 2013. Identification of the factors that result in obviousness rulings for biotech patents: an updated analysis of the US federal circuit decisions after KSR. Human Vaccines \& Immunotherapeutics 9:2490-2495.

Lumineau, F., and J.E. Oxley. 2012. Let's work it out (or we'll see you in court): litigation and private dispute resolution in vertical exchange relationships. Organization Science 23:820-834.

Lumineau, F., M. Frechet, and D. Puthod. 2011. An organizational learning perspective on the contracting process. Strategic Organization 9:8-32.

Madsen, P.M. 2009. These lives will not be lost in vain: organizational learning from disaster in US coal mining. Organization Science 20:861-875.

Madsen, P.M., and V. Desai. 2010. Failing to learn? The effects of failure and success on organizational learning in the global orbital launch vehicle industry. Academy of Management Journal 53:451-476.

Mayer, K.J., and N.S. Argyres. 2004. Learning to contract: evidence from the personal computer industry. Organization Science 15:394-410.

Meyer, A.D. 1982. Adapting to environmental jolts. Administrative Science Quarterly 27:515-537.

Miner, A.S., J.Y. Kim, I.W. Holzinger, and P. Haunschild. 1999. Fruits of failure: organizational failure and population-level learning. In Population-level learning and industry change, advances in strategic management, Vol. 16, ed. A.S. Miner, P. Anderson

Miozzo, M., and D. Grimshaw. 2011. Capabilities of large services outsourcing firms: the 'outsourcing plus staff transfer model' in EDS and IBM. Industrial and Corporate Change 20:909-940.

Moore, K.A. 2003. Xenophobia in American courts. Northwestern University Law Review 97:1497-1550.

Mowery, D.C., J.E. Oxley, and B.S. Silverman. 1996. Strategic alliances and interfirm knowledge transfer. Strategic Management Journal 17:77-91.

Niosi, J., and F.T. Tschang. 2009. The strategies of Chinese and Indian software multinationals: implications for internationalization theory. Industrial and Corporate Change 18:269-294.

Ocasio, W. 1997. Towards an attention-based view of the firm. Strategic Management Journal 18:187-206.

Polidoro, F., Jr, and P.K. Toh. 2011. Letting rivals come close or warding them off? The effects of substitution threat on imitation deterrence. Academy of Management Journal 54:369-392.

Van Pottelsberghe de la Potterie, B. 2011. The quality factor in patent systems. Industrial and Corporate Change 20:1755-1793.

Rerup, C. 2009. Attentional triangulation: learning from unexpected rare crises. Organization Science 20:876-893.

Rivette, K.G., and D. Kline. 2000. Discovering new value in intellectual property. Harvard Business Review 78:54-66.

Salgado, S.R., W.H. Starbuck, and J.M. Mezias. 2002. The accuracy of managers' perceptions: a dimension missing from theories about firms. In The economics of choice, change, and organizations: essays in memory of Richard M. Cyert, ed. J.G.M.M. Augier. Cheltenham: Edward Elgar.

Schilling, M.A., P. Vidal, R.E. Ployhart, and A. Marangoni. 2003. Learning by doing something else: variation, relatedness, and the learning curve. Management Science 49:39-56.

Schliesser, P. 2015. Patent litigation and firm performance: the role of the enforcement system. Industrial and Corporate Change 24:307-343.

Sitkin, S.B. 1992. Learning through failure-the strategy of small losses. Research in Organizational Behavior 14:231-266.

Somaya, D. 2003. Strategic determinants of decisions not to settle patent litigation. Strategic Management Journal 24:17-38.

Somaya, D. 2012. Patent strategy and management: an integrative review and research agenda. Journal of Management 38:1084-1114. 
Starbuck, W.H. 2009. Cognitive reactions to rare events: perceptions, uncertainty, and learning. Organization Science 20:925-937.

Tansey, R., M. Neal, and R. Carroll. 2005. 'Get rich, or die trying': lessons from Rambus' high-risk predatory litigation in the semiconductor industry. Industry and Innovation 12:93-115.

Teece, D.J. 1986. Profiting from technological innovation: implications for integration, collaboration, licensing and public-policy. Research Policy 15:285-305.

Teece, D.J., G. Pisano, and A. Shuen. 1997. Dynamic capabilities and strategic management. Strategic Management Journal 18:509-533.

The Economist. 2010. The great patent battle

Vanneste, B.S., and P. Puranam. 2010. Repeated interactions and contractual detail: identifying the learning effect. Organization Science 21:186-201.

Whitley, R. 2002. Developing innovative Competences: the role of institutional frameworks. Industrial and Corporate Change 11:497-528.

Xi, L., L. Lei, and W. Guisheng. 2009. Evolution of the Chinese automobile industry from a sectoral system of innovation perspective. Industry and Innovation 16:463-478.

Zhao, M. 2006. Conducting R\&D in countries with weak intellectual property rights protection. Management Science 52:1185-1199.

Zollo, M. 2009. Superstitious learning with rare strategic decisions: theory and evidence from corporate acquisitions. Organization Science 20:894-908. 